\title{
Cribriform-morular variant of papillary thyroid carcinoma with poorly differentiated features: report of a case and review of the literature
}

\author{
Kusum L. Sharma ${ }^{1}$, Ravi B. Singh ${ }^{2}$, Nisreen Fidda ${ }^{3}$ and Ricardo V. Lloyd ${ }^{1 *}$
}

\begin{abstract}
Introduction: Cribrifrom-morular variant of papillary thyroid carcinoma (CMVPTC) is an uncommon thyroid neoplasm that occurs predominantly in women and is sometime associated with familial adenomatous polyposis (FAP). Some of these tumors may undergo dedifferentiation to poorly differentiated thyroid carcinoma (PDTC). We describe a rare case of this carcinoma in a women without a history of FAP.

Case presentation: A 49-year-old woman with a history of breast carcinoma presented with a thyroid mass. A CMVPTC was diagnosed after excision. There was no history of FAP. Histological examination showed classical features of CMVPTC in most areas, but about 20\% of the carcinoma showed features of a poorly differentiated carcinoma with a solid pattern of growth, increase mitotic activity and a high Ki-67 proliferative index (25\%). Immunohistochemical stains were positive for nuclear and cytoplasmic beta catenin staining. These special studies supported the diagnosis.

Conclusion: CMVPTC with dedifferentiation to PDTC is a rare carcinoma with only 4 previous documented cases in the literature. This aggressive variant of thyroid carcinoma is more common in females, as is CMVPTC, and is often associated with an aggressive biological course. The cases usually express nuclear beta catenin and estrogen, progesterone and androgen receptors have been reported in some cases. Some cases may have somatic alterations of the APC gene and TERT promoter mutations. These carcinomas may metastasize to lung, bones and lymph nodes. Because of its aggressive behavior, patient with this diagnosis should be treated aggressively to control disease spread and mortality from the carcinoma.
\end{abstract}

Keywords: Cribriform morular variant of papillary thyroid carcinoma, Thyroid carcinoma, Familial adenomatous polyposis, Ki-67

\footnotetext{
* Correspondence: RVLloyd@wisc.edu

${ }^{1}$ Department of Pathology, University of Wisconsin School of Medicine and

Public Health, Madison, WI 53705, USA

Full list of author information is available at the end of the article
}

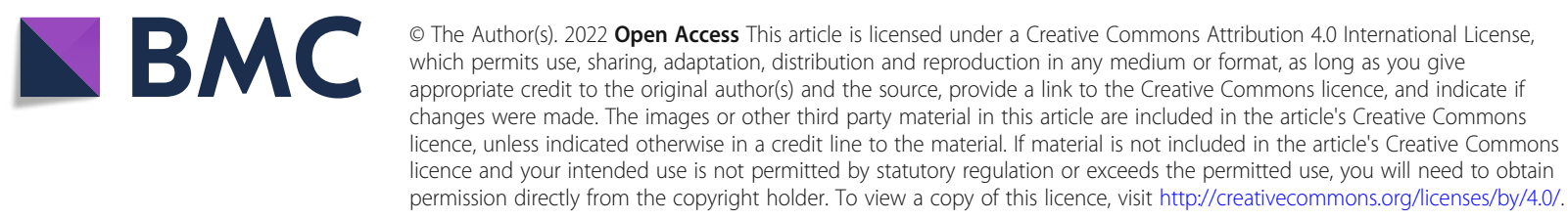




\section{Background}

Papillary carcinoma of thyroid (PTC), the most common type of the thyroid carcinoma is the most common endocrine maligancy. The prevalence of thyroid carcinoma has been increasing globally, mostly due to the increased detection of small papillary carcinomas (Rosai et al. 2017). CMVPTC has been recognized as a rare histologic variant of PTC and as a representative histotype of primary inherited thyroid cancers (LiVolsi et al. 2004). CMVPTC is characterized by the presence of a cribriform pattern of growth and morular formations. The tumor is very rare, representing $0.16 \%$ of 4194 papillary carcinomas in a large series. It develops in a sporadic form, or as an extraintestinal component of the familial adenomatous polyposis syndrome, and it may be the initial clinical manifestation of FAP. It is seen predominantly in females (Rosai et al. 2017).

CMVPTC can harbor germline or somatic (CameselleTeijeiro et al., 1999) mutation of adenomatous polyposis coli $(A P C)$ gene or somatic mutation of beta catenin (CTNNB1) gene (Xu et al. 2003). Mutations in any of the two genes result in disrupted degradation of betacatenin and subsequent aberrant nuclear expression of the protein, leading to Wnt signal transduction-targeted genes transcription. (McDonald et al. 2009). Nuclear immunoreactivity for beta -catenin, the hallmark of wnt pathway activation, is common. Wnt signaling is activated in the familial tumors because of germline loss of function mutations of the $A P C$ gene, and in the sporadic ones because of somatic $A P C$ mutations or due to somatic mutations in exon 3 of the beta -catenin gene that stabilize the beta -catenin protein, preventing its degradation and promoting its accumulation in the nucleus (Rosai et al. 2017).

CMVPTC is usually an encapsulated low-grade carcinoma with an intimate admixture of cribriform, follicular, papillary, trabecular, and solid patterns of growth; round squamoid morular structures. The neoplastic cell nuclei are not particularly clear but exhibit variable amounts of grooves and pseudo inclusions in the morulaes, however, neoplastic cells have some optically clear nuclei. These are different from those of conventional papillary carcinoma and like the nuclei seen in morulae-containing tumors at other sites, due to the accumulation of biotin (Rosai et al. 2017).

PDTCs show limited evidence of structural follicular cell differentiation and fall in between two extremes (well differentiated papillary and follicular carcinoma and anaplastic carcinoma), in terms of both morphologic appearance and clinical behaviour. PDTCs are rare thyroid carcinomas, less than $2 \%$ in the United States. Iodine deficiency likely represents a risk factor based on the association of poorly differentiated carcinoma with long standing goiter. PDTC occurs in an older age group, with a mean age of 55-65 years (Volante et al. 2007).
In many cases poorly differentiated tumors exhibit a complex pattern, and poorly differentiated areas can be intermixed with a variety of growth patterns, including areas of well-differentiated papillary or follicular carcinoma. Here we present a case of a CMVPTC with poorly differentiated component.

\section{Case presentation}

This is a case of 49 year old female who presented with a left thyroid mass, measuring $4.5 \mathrm{~cm}$ in greatest dimension. Fine needle aspiration (FNA) biopsy was reported as suspicious for PTC. She underwent left thyroid lobectomy. As the patient was adopted, family history including a history of FAP was not known. She had a history of breast carcinoma, diagnosed at age of 32 and was treated with mastectomy, chemotherapy and radiation.

\section{Histologic examination}

Histologic examination of the nodule from the lobectomy specimen revealed tumor cells with cribriform, papillary and morular pattern (Fig. 1A) containing follicles without colloid, some papillary formations with cells that had abundant eosinophilic cytoplasm, hyperchromatic nuclei with grooves and pseudo-inclusions with areas of solid and trabecular growth pattern, composed of larger more pleiomorphic and oxyntic cells. There was a focal angioinvasion (Fig. 1B). The tumor also showed capsular invasion (Fig. 1B). There was increased mitotic activity with upto 3 mitoses per 10 high power fields (Fig. 1C).

\section{Immunohistochemistry}

The Ki-67 proliferative index was $25 \%$ in hot areas (Fig. 1D) (Table 1). The carcinoma was positive for beta catenin with nuclear and cytoplasmic staining (Fig. 2A), stains for keratin, TTF-1 and CK19 were positive while HBME-1 and thyroglobulin were focally positive. Estrogen receptor (ER) (Fig. 2B), progesterone receptor (PR) (Fig. 2C) and androgen receptor (AR) (Fig. 2D) proteins were all diffusely positive. The tumor cells were negative for BRAF, P53, CEA, Chromogranin, Synaptophysin, Calcitonin and CDX2.

\section{Follow up}

After the diagnosis was made, the patient had a completion thyroidectomy and histological examination showed multinodular hyperplasia but no residual malignancy. She subsequently received radioactive iodine ablation treatment. Her post therapy whole body radioactive iodine scan showed no evidence of metastasis. Follow up in 21 months has shown no evidence of recurrence or metastasis. 


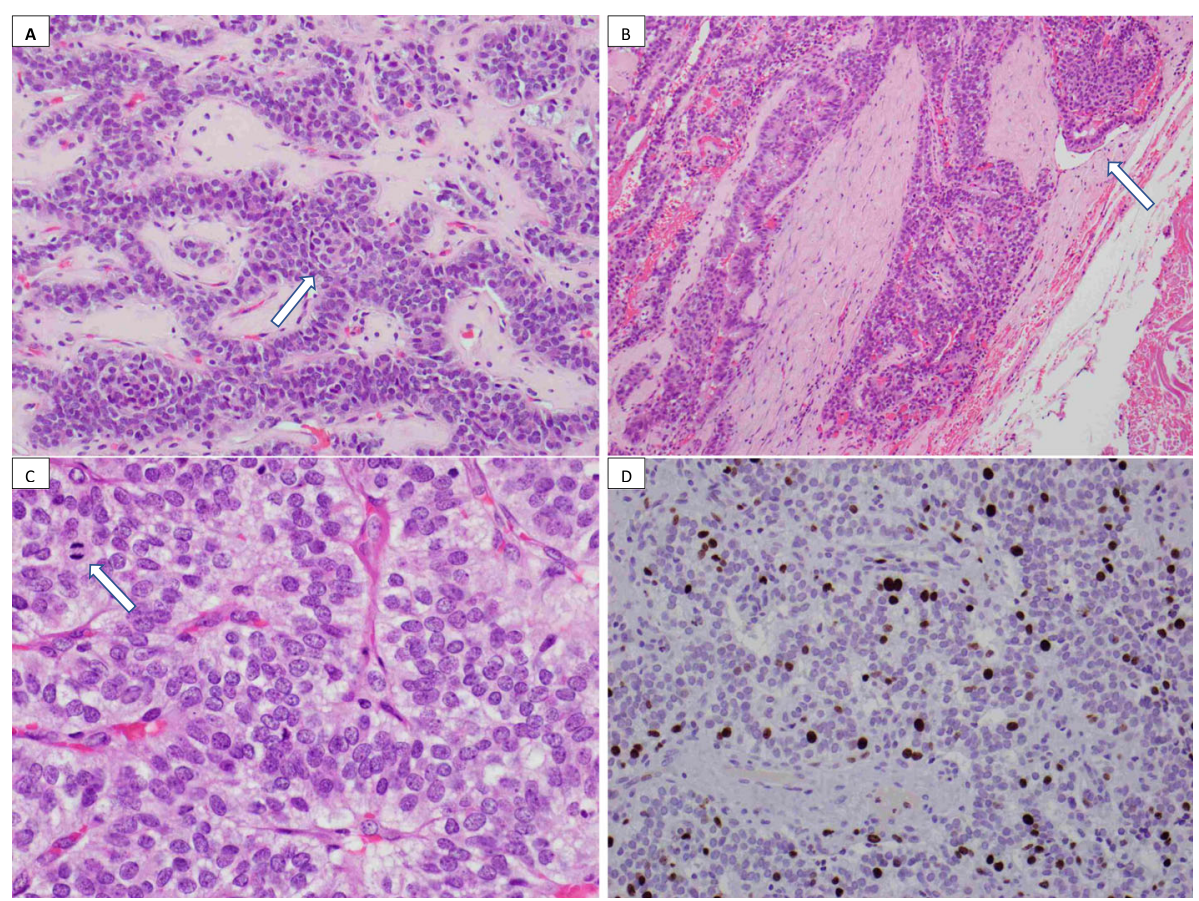

Fig. 1 Cribriform-morular variant of papillary thyroid carcinoma (CMVPTC) with dedifferentiated features. A The cribriform component of the tumor has luminal structures without colloid and prominent cribriform structures lined by stratified tall cells. A morule is also present (arrow) (X20) B Capsular invasion and a focus of tumor cells entering a blood vessel (arrow) in the capsule in the CMVPTC. (X10). Increase mitotic activity in the solid portion of the carcinoma with up to three mitoses per 10 high power field. A mitotic figure is shown (arrow). D Ki-67

immunostaining shows increased proliferative index in the solid area of the carcinoma (X40)

\section{Discussion and conclusion}

In this report we present a case of a thyroid tumor with both CMVPTC and PDTC component but without metastasis. These 2 components fit the pathological criteria of each of the 2 histotypes (LiVolsi et al. 2004; Harach et al. 1994; Sobrinho-Simões et al. 2004; Volante et al. 2007; Nakazawa et al. 2013). Although both components coexisted in the same nodule, the CMVPTC and the PDTC component had clear distinction. Until now there have been only 3 cases of CMVPTC which showed poorly differentiated features and another case of cribriform morular variant of PTC that metastasized to the lung and the metastatic tumor showed poorly differentiated features (Table 1).
CMVPTC is a rare thyroid malignancy that is sometimes associated with FAP, but usually occurs as a sporadic neoplasm (Rosai J et al., Rosai et al. 2017). One investigator (Bussy 1912) recognized in 1912 the association of intestinal adenomatous polyposis with extracolonic manifestations, including a "goiter." Another investigator (Crail 1949) reported in 1949 the first case of papillary adenocarcinoma of the thyroid ("with very little colloid") associated with multiple primary malignancies arising in the rectum and brain but, it was in 1968 that some investigators (Camiel et al. 1968) suggested that there was a relationship of familial adenomatous polyposis with thyroid carcinoma for the first time. Chan and co-workers (Chan and Loo 1990) described rare papillary thyroid carcinomas with a cribriform

Table 1 Reported cases of cribriform-morular variant of papillary thyroid carcinoma with poorly Differentiated Features

\begin{tabular}{lllllll}
\hline Reference & Age & Sex & FAP & Metastasis & Mutation & Ki-67 Index $^{\mathbf{a}^{2}}$ \\
\hline Nakazawa, et al. & 35 & F & - & lung, bone & Somatic APC alteration & $15-20 \%$ \\
Oh, et al. & 45 & F & - & bone, lymph node & TERT promoter & $--{ }^{---}$unknown \\
Tsuji, et al. & 28 & F & - & lung & Negative for BRAF & $40.2 \%$ \\
Corean, et al. & 29 & F & - b & none & Somatic APC alteration & $15 \%$ \\
Present Case & 49 & F & - & none & Negative for BRAF & 25 \\
\hline
\end{tabular}

${ }^{a} \mathrm{Ki}-67$ in primary tumor

${ }^{\mathrm{b}}$ Germline alterations of the APC gene 


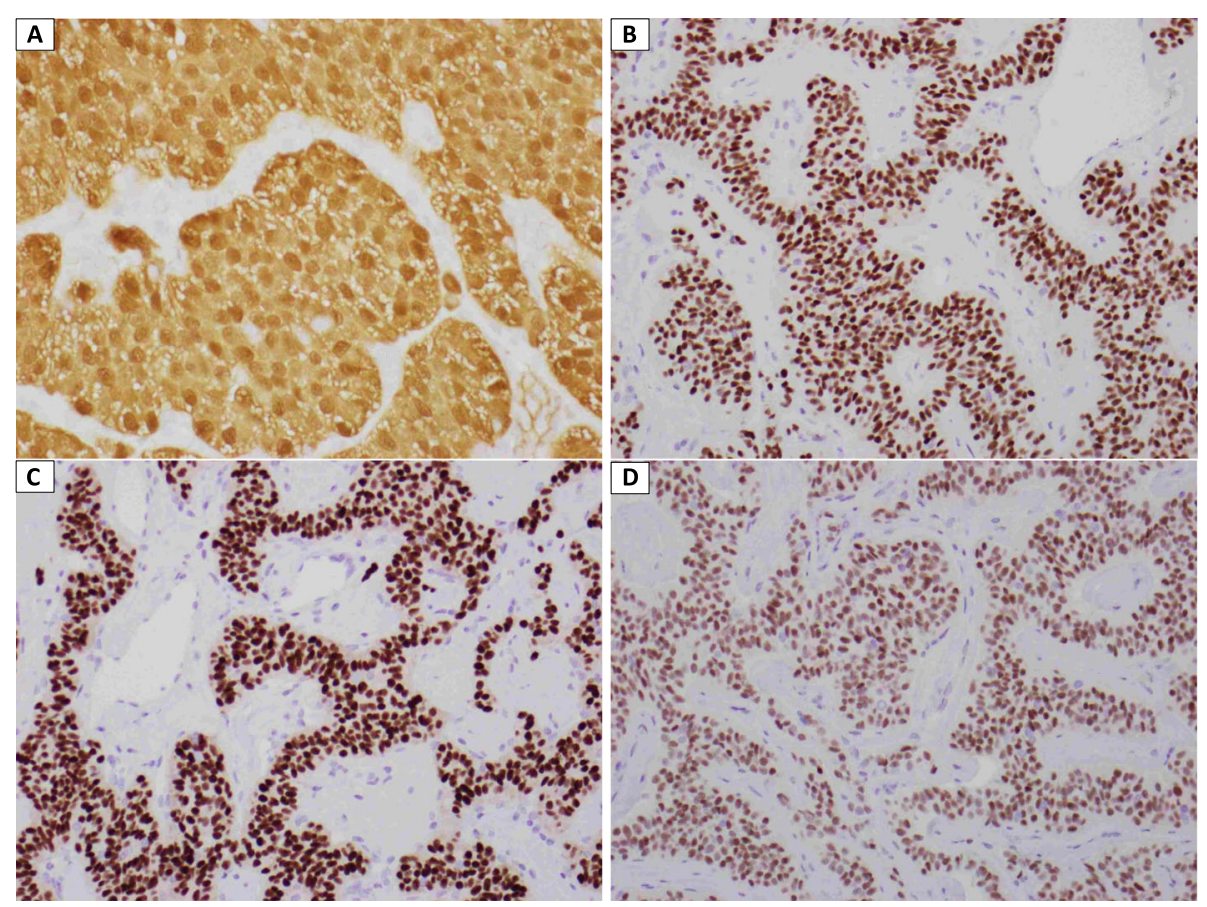

Fig. 2 Immunohistochemical staining in the CMVPTC. A Staining for beta catenin shows nuclear and cytoplasmic staining in many tumor cells (X40). B Strong staining for Estrogen receptor protein is diffusely present in the nuclei of the tumor cells (X20). C Strong staining for Progesterone receptor protein is diffusely present in the nuclei of the tumor cells tumor cells (X20). D Moderate staining for Androgen receptor protein is diffusely positive in the nuclei of the tumor cells (X20)

pattern, and soon after Harach (Harach et al. 1994), recognized the familial adenomatous polyposisassociated thyroid carcinoma as a distinctive type of follicular cell neoplasm. CMVPTC is more frequently observed in women than in men. The mean age at diagnosis is 26 years (range 8-61 years), both for FAPassociated and for sporadic CMVPTC. In FAPassociated cases (about $60 \%$ of the total), thyroid carcinoma diagnosis precedes that of FAP in up to $40 \%$ of the cases. This variant seems more common in Asia (65\%) and in America (23\%), than in other parts of the world. (Cameselle-Teijeiro et al. 2018).

Various authors have reviewed the molecular signature of the inherited and sporadic forms of CMVPTC and have found mutations in the $A P C$ gene in both forms. These observations suggest that the $A P C$ gene may often play a role in tumorigenesis. Other mutations have also been recognized in CMVPTC, with the most common being those in the beta-catenin gene. However, beta catenin mutations have only been identified as somatic, not germline, in patients with CMVPTC. (Cameselle-Teijeiro et al., 1999; Xu et al. 2003; Corean et al. 2019). Both $A P C$ and beta catenin are involved in the Wnt signaling pathway, and mutations that involve the constitutive activation of the Wnt signaling pathway can lead to cancer (Logan and Nusse 2004).
PDTC has an intermediate behavior between welldifferentiated (papillary and follicular) carcinomas and undifferentiated (anaplastic) carcinoma. The mean 5year survival of patients with PDTC is about $50 \%$ (Sobrinho-Simões et al. 2004). The criteria for making the diagnosis of PDTC were summarized in the Turin proposal (Volante et al. 2007). The Turin consensus criteria currently define poorly differentiated carcinoma. In many cases poorly differentiated tumors exhibit a complex pattern, and poorly differentiated areas can be intermixed with a variety of growth patterns, including areas of well-differentiated papillary or follicular carcinoma (Rosai et al. 2017).

Nishida and coworkers (Nishida et al., Nishida et al. 1999) showed that focal PDTC, defined as comprising < $10 \%$ of a PDTC, versus diffuse PDTC had statistically better outcomes. Their analysis indicated that diffuse PDTC was an independent risk factor for total, local, regional lymph node, and distant recurrences. The focal PDTCs had morbidity and mortality outcomes like their well-differentiated cohort. PDTC, in contrast to CMVP $\mathrm{TC}$, is more common in older women and has an aggressive behavior.

In general, patients with CMVPTC follow an indolent clinical course with a favorable outcome that is analogous to that of patients with conventional PTC. CMVP $\mathrm{TC}$ is considered to be a low-grade thyroid cancer with 
only rare reports of aggressive behavior with regional or distance metastasis (Oh et al. 2017). Although about 150 cases of CMVPTC have been reported to date, only 7 patients died from the disease (Harach et al. 1994; Cameselle-Teijeiro et al. 2009; Fenton et al. 2001). The proliferation index in CMVPTC is usually low (Cameselle-Teijeiro et al., 1999; Xu et al. 2003). None of the CMVPTC on record had higher than $6 \%$ of proliferation index, except for the unusual CMVPTC reported by Cameselle-Teijeiro and co-workers (Cameselle-Teijeiro et al. 2009). Nakazawa and co-workers (Nakazawa et al. 2013) emphasized that the high MIB-1 index (15\%) and the frequent mitotic figures in the CMVPTC component in their case would indicate that the whole neoplasm had high-grade malignant potential from inception.

One group of investigators (Cameselle-Teijeiro et al. 2009) reported on a case of CMVPTC with neuroendocrine differentiation that metastasized to the lung and brain. Since this carcinoma was not combined with a follicular-derived carcinoma, it could represent a collision tumor and was not included in our series summarized in Table 1.

A recent report (Oh et al. 2017) summarized a case of 45- year- old female without FAP who presented with multiple lymph nodes and bone metastasis. After total thyroidectomy and radioactive iodine remnant ablation; histopathologic examination revealed CMVPTC component and molecular analysis of both the primary and metastatic tumor tissues revealed a telomerase reverse transcriptase (TERT) promoter mutation, but absence of APC, BRAF, KRAS, NRAS, HRAS, and PIK3CA mutations. Mutations in the TERT gene promoter increases telomerase activity and plays an important role in cellular immortality and tumorigenesis (Mocellin et al. 2013). These mutations have been observed in aggressive thyroid cancers and are associated with older age, recurrence, and poor prognosis (Kwon et al. 2015).

In a recent report (Nakazawa et al. 2013) a woman had metastatic thyroid carcinoma with both CMVPTC and PDTC components. The two components shared some of the cytomorphological and immunohistochemical features as well as the same genetic profile. The authors suggested that the tumor showed morphological heterogeneity and/or dedifferentiation. This assumption was supported by immunohistochemical study that showed that the neoplastic cells of the PDTC component displayed intermediate immunohistochemical characteristics between the morular cells and main neoplastic cells of the CMVPTC component. The PDTC could occur either de novo or arise from preexisting well-differentiated thyroid carcinomas, more likely PTCs, that can be regarded as precursor lesions (SobrinhoSimões et al. 2004). In addition to this evidence and considering the clinicopathological features of the 2 components (CMVPTC and PDTC). They suggested that the preexisting CMVPTC could have progressed or transformed into PDTC.

The positive APC immunohistochemistry that may be seen in CMVPTC may suggest an absence of APC mutations (Tsuji et al. 2018). In conventional PTCs, betacatenin expression is usually upregulated, in comparison with nonneoplastic and benign thyroid lesions. Representative genetic alterations of PTC are RET/PTC rearrangements and BRAF and RAS mutations, which are usually mutually exclusive with BRAF being the most common genetic alteration. APC gene mutation has not been reported in PTC. (Nakazawa et al. 2013). In CMVP TCs, nuclear and cytoplasmic expression of $\beta$-catenin are aberrantly detected, because of mutations of the APC gene (germline or somatic) and/or CTNNB1 gene (somatic). Mutation of BRAF gene has not been reported in any CMVPTCs, including the unusual CMVPTC with neuroendocrine features (Cameselle-Teijeiro et al. 2013) In PDTC, aberrant expression of $\beta$-catenin and CTNNB1 gene mutations have been detected in highgrade cases (Nakazawa T et al., Nakazawa et al. 2013). BRAF mutation is found in PDTCs transformed from PTCs, and is rarely, if ever, detected in PDTC arising from follicular thyroid carcinomas (Nakazawa et al. 2013). In the case form Nakazawa et al., aberrant immunoreactivity for $\beta$-catenin was detected in both CMVP TC and PDTC components. Molecular genetic analyses showed that the 2 components harbored the same somatic APC gene mutation and lacked CTNNB1 gene mutation. In their case BRAF mutation was absent in both the CMVPTCs and the PDTC components. The data suggests that mutations of APC and CTNNB1 genes, involving Wnt signal pathway, are more important than the PTC-related genetic alterations in the carcinogenic process of CMVPTC (Kimura et al. 2003).

A recent report of a case of 29-year-old female with bilateral thyroid nodules without metastasis in which the carcinoma showed both CMVPTC and PDTC components with an interesting genetic alteration provided insight into the molecular mechanisms in these cancers, (Corean et al. 2019). The patient had a known history of constitutional deletion of the short arm of chromosome 5 which encompasses the APC gene locus however the patient did not have any sign and symptoms of FAP. Immunohistochemistry showed strong expression of betacatenin by immunohistochemistry in both the CMVPTC and PDTC components, supporting a disruption in the Wnt signaling pathway. The authors further analyzed the molecular components which revealed a single nucleotide deletion within exon 14 of the APC gene, found only in the PDTC component of the tumor which resulted in a frameshift of the protein coding sequence beginning at amino acid 1214 and created a premature 
stop codon after 51 new amino acids. The CMVPTC component was distinguished by a single nucleotide substitution located one base pair downstream of exon 12 of the APC gene. There was a heterozygous germline deletion of the APC gene locus on chromosome $5 \mathrm{q} 21$ with 2 morphologically distinct areas in the same tumor, each harboring a different somatic APC genetic alteration. The fact that there were distinct genetic alterations unique to the PDTC component raised the possibility that this component of the tumor was distinct, not only morphologically, but genetically as well. The authors suggested that the genetic findings therefore resulted from dedifferentiation of a CMVPTC tumor via a branch (clonal) splice site mutation with subsequent intratumoral heterogeneity not explained by any identifiable common mutation, at least not one identified by the assay applied in their study.

In a recent study of 33 cases of patients with CMVP TC the authors had two cases that showed dedifferentiation. However, follow-up information about these cases was not available and the Ki-67 proliferative index was not reported (Boyraz et al. 2021). The authors suggested that these were thyroid malignancy of uncertain cytogenesis.

A common pathway from well differentiated thyroid carcinomas to undifferentiated thyroid carcinomas is epithelial mesenchymal transition (EMT). During EMT tumor cells change shape from an epithelial morphology to spindled mesenchymal- type cells and there are associated cellular and molecular changes such as increased expression of Snail, Slug, and Twist during the mesenchymal phase of the transition (Buehler et al. 2013; Hardin et al. 2014). A significant portion of anaplastic carcinomas have been reported to be associated with papillary thyroid carcinomas suggesting development by EMT during this transformation (Albores Saavedra et al., Albores-Saavedra et al. 2007). Similar findings for PDTC have not been reported; however, this does not exclude the possibility of molecular and cellular transformation without obvious mesenchymal changes as might occur in CMVPTC to poorly differentiated carcinomas. More work is needed to define the mechanisms regulating transformation in these tumors.

Our case showed high expression of ER, PR, and AR proteins. The significance of these steroid receptor proteins in thyroid tissues have been controversial. Some authors have found no differences in biological behavior when these receptors are present (Diaz et al., 1991) while others have found that thyroid carcinomas expressing these receptors may have a less aggressive biological course (Sturmiolo et al. 2016; Tavanger et al., Tavangar et al. 2007). In contrast others have reported a more aggressive course in tumors expressing these steroid hormone receptors. (Magni et al. 2012). The significance of the presence of the three receptor proteins in the present case suggest that anti-hormonal therapy may sometimes be useful in patients with aggressive thyroid cancers expressing these hormone receptors.

In conclusion, rare cases of CMVPTC may show dedifferentiation and more aggressive biological behavior as documented by several reported cases in the recent pathology literature. These carcinomas have unique histopathological features of CMVPTC and PDTC with increased mitotic activity, an increased Ki-67 proliferative index along with nuclear expression of beta catenin that should be helpful in making the diagnosis.

\section{Abbreviations \\ CMVPTC: Cribriform-morular variant of papillary thyroid carcinoma; PDTC: Poorly differentiated thyroid carcinoma; FAP: Familial adenomatous polyposis; APC: Adenomatous polyposis coli gene; CTNNB1: Beta catenin gene; ER: Estrogen receptor; PR: Progesterone receptor; AR: Androgen receptor}

\section{Acknowledgements}

The authors thank the patient described in the report for allowing them to share the details. We also thank the histology laboratory for performing all the immunohistochemical stains.

\section{Authors' contributions}

KLS and RBS wrote the manuscript under supervision of RVL. NF was the patient consultant and did the work up and made the diagnosis of the original carcinoma. All authors read and approved the final manuscript.

\section{Funding}

The authors received no specific funding for the work.

Availability of data and materials

Data sharing is not applicable for this article as no datasets were presented or analyzed during the current study.

\section{Declarations}

Ethics approval and consent to participate

Ethical approval is not required at our institution to publish an anonymous case report.

\section{Consent for publication}

Yes

\section{Competing interests}

The authors declare that they have no competing interest.

\section{Author details}

${ }^{1}$ Department of Pathology, University of Wisconsin School of Medicine and Public Health, Madison, WI 53705, USA. ²Department of Medicine, SUNY Upstate Medical University, Syracuse, NY 13210, USA. ${ }^{3}$ CellNetix, 413 Lily Road NE, Olympia, WA 98506, USA.

Received: 1 November 2021 Accepted: 28 November 2021

Published online: 08 January 2022

\section{References}

Albores-Saavedra J, Mercedes H, Sosa-Sanchez S, Simpson K, Arturo A. Histologic variants of papillary and follicular carcinomas associated with anaplastic spindle cell and giant cell carcinomas of the thyroid. An analysis of rhabdoid and thyroglobulin inclusions. Am J Surg Pathol. 2007;31(5):729-36. https:// doi.org/10.1097/01.pas.0000213417.00386.74.

Boyraz B, Sadow PM, Asa SL, Dias Santagate D, Nose V, Mete O. CribriformMorular thyroid carcinoma is a distinct thyroid malignancy of uncertain 
cytogenesis. Endocri Pathol. 2021;32(3):327-35. https://doi.org/10.1007/s12 022-021-09683-0.

Buehler D, Hardin H, Shan W, Montemayor-Garcia C, Rush PS, Asioli S, Chen H, Lloyd RV. Expression of epithelial-transition regulators SNAIL2 and TWIST1 in thyroid carcinomas. Modern Pathol. 2013;26(1):54-61. https://doi.org/10.1038/ modpathol.2012.137.

Bussy DC. Un cas de polypose adenomateuse generalisee a tout l'intestin. Arch Fr Mal Appl Dig. 1912;6:278-89.

Cameselle-Teijeiro J, Chan JK. Cribriform-morular variant of papillary carcinoma: a distinctive variant representing the sporadic counterpart of familial adenomatous polyposis-associated thyroid carcinoma? Mod Pathol. 1999; 12(4):400-11.

Cameselle-Teijeiro J, Menasce LP, Yap BK. Cribriform-morular variant of papillary thyroid carcinoma: molecular characterization of a case with neuroendocrine differentiation and aggressive behavior. Am J Clin Pathol. 2009;131(1):134-42. https://doi.org/10.1309/AJCP7ULSOVSISBEB.

Cameselle-Teijeiro J, Ruiz-Ponte C, Loidi L, Suarez-Penaranda J, Baltar J, SobrinhoSimoes M. Somatic but not germline mutation of the APC gene in a case of cribriform-morular variant of papillary thyroid carcinoma. Am J Clin Pathol. 2013;115(4):486-93. https://doi.org/10.1309/T9CC-JNMD-1WGP-YPAF.

Cameselle-Teijeiro JM, Peteiro-González D, Caneiro-Gómez J, Sánchez-Ares M, Abdulkader I, Eloy C, Melo M, Amendoeira I, Soares P, Sobrinho-Simões M. Cribriform-morular variant of thyroid carcinoma: a neoplasm with distinctive phenotype associated with the activation of the WNT/ $\beta$-catenin pathway. Mod Pathol. 2018;31(8):1168-79. https://doi.org/10.1038/s41379-018-0070-2.

Camiel MR, Mulé JE, Alexander LL, Benninghoff DL. Association of thyroid carcinoma with Gardner's syndrome in siblings. N Engl J Med. 1968;278(19): 1056-8. https://doi.org/10.1056/NEJM196805092781908.

Chan JK, Loo KT. Cribriform variant of papillary thyroid carcinoma. Arch Pathol Lab Med. 1990;114(6):622-4.

Corean J, Furtado LV, Kadri S, Segal JP, Emerson LL. Cribriform-Morular variant of papillary thyroid carcinoma with poorly differentiated features: a case report with Immunohistochemical and molecular genetic analysis. Int I Surg Pathol May. 2019;27(3):294-304. Epub 2018 Sep 3. PMID: 30176755. https://doi.org/1 $0.1177 / 1066896918796946$.

Crail HW. Multiple primary malignancies arising in the rectum, brain, and thyroid; report of a case. U S Nav Med Bull. 1949;49(1):123-8.

Diaz NM, Mazoujian G, Wick MR. Estrogen-receptor protein in thyroid neoplasms. An immunohistochemical analysis of papillary, follicular carcinoma and follicular adenoma. Archiv Pathology \& Lab Med. 1991;115:1203-7.

Fenton PA, Clarke SE, Owen W, Hibbert J, Hodgson SV. Cribriform variant papillary thyroid cancer: a characteristic of familial adenomatous polyposis. Thyroid. 2001;11(2):193-7. https://doi.org/10.1089/105072501300042965.

Harach HR, Williams GT, Williams ED. Familial adenomatous polyposis associated thyroid carcinoma: a distinct type of follicular cell neoplasm. Histopathology. 1994;25(6):549-61. https://doi.org/10.1111/j.1365-2559.1994.tb01374.x.

Hardin H, Guo Z, Shan W, Montemayor-Garcia C, Asioli S, Yu XM, et al. The roles of epithelial-mesenchymal transition marker PRRX1 and miR-146b-5p in papillary thyroid carcinoma progression. Am J Pathol. 2014;184(8):2342-54. https://doi.org/10.1016/j.ajpath.2014.04.011.

Kimura ET, Nikiforova MN, Zhu Z, Knauf JA, Nikiforov YE, Fagin JA. High prevalence of BRAF mutations in thyroid cancer: genetic evidence for constitutive activation of the RET/PTC-RAS-BRAF signaling pathway in papillary thyroid carcinoma. Cancer Res. 2003;63(7):1454-7.

Kwon MJ, Rho YS, Jeong JC, Shin HS, Lee JS, Cho SJ, Nam ES. Cribriform-morular variant of papillary thyroid carcinoma: a study of 3 cases featuring the PIK3CA mutation. Hum Pathol. 2015;46(8):1180-8. https://doi.org/10.1016/j. humpath.2015.04.010.

LiVolsi VA, Albores Saavedra J, Asa SL. Papillary carcinoma. In: DeLellis RA, Lloyd RV, Heitz PU, Eng C, editors. World Health Organization classification of Tumours. Pathology and genetics of Tumours of endocrine organs. Lyon: IARC press; 2004. p. 57-66.

Logan CY, Nusse R. The Wnt signaling pathway in development and disease. Annu Rev Cell Dev Biol. 2004;20(1):781-810. https://doi.org/10.1146/annurev. cellbio.20.010403.113126.

Magni F, Capella V, Rotondi M, Leporati P, LaManna L, Ruggiero R, et al. Expression of estrogen and androgen receptors in differentiated thyroid cancer: an additional criterion to assess the patient's risk. Endocrine Rel Cancer. 2012;19:463-71.
McDonald BT, Tamai K, He X. Wnt/beta-catenin signaling: components, mechanisms, and diseases. Dev Cell. 2009;17(1):9-26. https://doi.org/10.1016/ j.devcel.2009.06.016.

Mocellin S, Pooley KA, Nitti D. Telomerase and the search for the end of cancer. Trends Mol Med. 2013;19(2):125-33.

Nakazawa T, Celestino R, Machado JC, Cameselle-Teijeiro JM, Vinagre J, Eloy C, Benserai F, Lameche S, Soares P, Sobrinho-Simões M. Cribriform-Morular variant of papillary thyroid carcinoma displaying poorly differentiated features. Int J Surg Pathol. 2013;21(4):379-89. https://doi.org/10.1177/1 066896912473355.

Nishida T, Katayama S, Tsujimoto M, Nakamura J. Clinicopathological significance of poorly differentiated thyroid carcinoma. Am J Surg Pathol. 1999;23(2):20511. https://doi.org/10.1097/00000478-199902000-00010.

Oh EJ, Lee S, Bae JS, Kim Y, Jeon S, Jung CK. TERT promoter mutation in an aggressive cribriform Morular variant of papillary thyroid carcinoma. Endocr Pathol. 2017;28(1):49-53 PMID: 27688081

Rosai J, Albores Savedra J, Asioli S, et al. Papillary thyroid carcinoma. In: Lloyd RV, Osamura RY, Klöppel G, et al., editors. World Health Organization classification of Tumours. Pathology and genetics of tumours of endocrine organs. 4th ed. Lyon: IARC press; 2017. p. 81-91.

Sobrinho-Simões M, Albores-Saavedra J, Tallini G. Poorly differentiated carcinoma. In: DeLellis RA, Lloyd RV, Heitz PU, Eng C, editors. World Health Organization classification of Tumours. Pathology and genetics of Tumours of endocrine organs. Lyon: IARC press; 2004. p. 73-6.

Sturmiolo G, Zafon C, Moleti M, Casstelivi J, Vermiglio F, Mesa J. Immunohistochemical expression of estrogen receptor-alpha and progesterone receptor in patients with papillary thyroid cancer. Eur Thyroid J. 2016;5(4):224-30. https://doi.org/10.1159/000452488.

Tavangar SM, Monajemzadeh M, Larijani B, Hoghpandat V. Immunohistochemical study of oestrogen receptors in 351 human thyroid glands. J. Singap Med J. 2007:48(8):744-7.

Tsuji H, Yasuoka H, Nakamura Y, Hirokawa M, Hiroshima T, Sakamaki Y, Miyauchi A, Tsujimoto M. Aggressive cribriform-morular variant of papillary thyroid carcinoma: report of an unusual case with pulmonary metastasis displaying poorly differentiated features. Pathol Int. 2018;68(12):700-5. https://doi.org/1 $0.1111 /$ pin. 12728 .

Volante M, Collini P, Nikiforov YE, Sakamoto A, Kakudo K, Katoh R, Lloyd RV LiVolsi VA, Papotti M, Sobrinho-Simoes M, Bussolati G, Rosai J. Poorly differentiated thyroid carcinoma: the Turin proposal for the use of uniform diagnostic criteria and an algorithmic diagnostic approach. Am J Surg Pathol. 2007;31(8):1256-64. https://doi.org/10.1097/PAS.0b013e3180309e6a.

Xu B, Yoshimoto K, Miyauchi A. Cribriform-morular variant of papillary thyroid carcinoma: a pathological and molecular genetic study with evidence of frequent somatic mutations in exon 3 of the beta-catenin gene. J Pathol. 2003;199(1):58-67. https://doi.org/10.1002/path.1225.

\section{Publisher's Note}

Springer Nature remains neutral with regard to jurisdictional claims in published maps and institutional affiliations.
Ready to submit your research? Choose BMC and benefit from:
- fast, convenient online submission
- thorough peer review by experienced researchers in your field
- rapid publication on acceptance
- support for research data, including large and complex data types
- gold Open Access which fosters wider collaboration and increased citations
- maximum visibility for your research: over $100 \mathrm{M}$ website views per year
At BMC, research is always in progress.
Learn more biomedcentral.com/submissions 